\title{
Fiscal Devaluation in a Small Open Economy ${ }^{1}$
}

\author{
Róbert Ambriško, CERGE-EI and Czech National Bank \\ robert.ambrisko@cerge-ei.cz
}

Fiscal devaluation, meaning a shift from payroll to indirect taxes, can be beneficial for a small open economy such as the Czech Republic. Using a structural fiscal DSGE model, I show that fiscal devaluation can boost real GDP growth by 0.5 percentage points in the first year, when a budget-neutral tax shift of the magnitude of $1 \%$ of GDP occurs from direct taxes to consumption tax. I also calculate fiscal multipliers for several revenue and expenditure categories of the government budget, the largest of which (after the first year) are government consumption (0.6), government investment (0.5), and social security contributions paid by employers (0.4). These results corroborate the hypothesis that the government can easily boost the economy by adjusting fiscal instruments appropriately.

Keywords: Bayesian

estimation, DSGE, fiscal

devaluation, fiscal multipliers,

fiscal policy, taxation

JEL Codes: C11, E32, E62, F41
Citation: Ambriško, R. (2019).

Fiscal Devaluation in a Small

Open Economy. Russian

Journal of Money and Finance, 78(1), pp. 67-88.

doi: $10.31477 /$ rjmf.201901.67

\section{Introduction}

The interaction between fiscal and monetary policy is of crucial importance for policy-makers in the government and central bank. The government often implements new fiscal measures or adjusts the parameters of fiscal instruments, either simultaneously or one at a time. One interesting example of simultaneous adjustment on the revenue side of the government budget is so-called fiscal devaluation. Fiscal devaluation is a shift from direct to indirect taxes in a manner which is budget-neutral for the government. The economic consequences

\footnotetext{
${ }^{1}$ I am grateful to Michal Kejak, Sergey Slobodyan, and anonymous referees for their helpful comments and suggestions. The model in this paper benefited from comments by Jan Babecký, Michal Franta, Philipp Hartmann, Josef Hollmayr, Marek Kapička, Marco Ratto, Jakub Ryšánek, Jan in't Veld, and Milan Výškrabka, participants at CNB seminars and the UECE Conference on Economic and Financial Adjustments in Europe, Lisbon, 2013. I also thank Paul Whitaker and Gray Krueger for English proofreading. The views expressed in this article are those of the author and do not necessarily reflect the views of the affiliated institutions. All errors remaining in this text are the responsibility of the author.
} 
of fiscal devaluation in an open economy are as follows. A decrease in direct taxes lowers firms' labour costs, reduces domestic producers' prices, and increases the price competitiveness of exports. On the other hand, higher indirect taxes make imports more expensive, while leaving exports unaffected. Overall economic growth is supported by an improved trade balance and increased domestic demand.

This paper contributes to the literature by analysing the effects of fiscal devaluation in a small open economy using a structural fiscal DSGE model. I also calculate a detailed set of fiscal multipliers for the Czech Republic. More specifically, I address the following research questions. First, could fiscal devaluation make the Czech economy better off? What would the real GDP gain be in this case? Second, how much do fiscal discretionary measures contribute to real GDP growth? In other words, what is the size and sign of these fiscal multipliers?

In addressing these research questions, I utilise a structural fiscal DSGE model, a slightly modified version of the model used in Ambriško et al. (2015). This model is essentially an extended version of the Czech National Bank's (CNB) g3 model (Andrle et al., 2009) with a more comprehensive fiscal block. The fiscal extensions comprise the following features: i) 'rule-of-thumb' households as in Galí et al. (2007), ii) productive government consumption and capital (Barro 1981; Baxter and King 1993), iii) unemployment as proposed by Galí (2011), iv) a rich set of fiscal instruments on the revenue and expenditure side of the government budget, v) estimated fiscal rules with feedback effects. The model is estimated by Bayesian techniques on Czech data over the period 2000-2015, covering more than ten fiscal variables.

Given the lack of empirical literature on fiscal devaluation for the Czech Republic, I evaluate the impact on the Czech economy of a hypothetical budgetneutral tax shift from direct to indirect taxes. The model's simulations show that the government can easily boost the economy by adjusting the composition of taxes, from direct to indirect, appropriately. Specifically, real GDP growth can be boosted by 0.5 percentage points (p.p.) in the first year when a shift of a magnitude of $1 \%$ of GDP occurs from direct to indirect taxes. The model also evaluates fiscal devaluation resulting from the 2008 Stabilisation Reform, finding positive real GDP gains from past tax changes.

As regards the real GDP fiscal multipliers, the model suggests that the largest multipliers after the first year are associated with government consumption (0.6), government investment ( 0.5$)$, and social security contributions paid by employers (0.4). These are followed by consumption tax, wage tax, and unemployment benefits, with fiscal multipliers roughly equal to 0.3 . Lower fiscal multipliers are found for other social benefits, lump-sum taxes (both 0.2), and capital tax (0.1). These values for fiscal multipliers are slightly higher than the values calculated in a similar paper by Klyuev and Snudden (2011), in which the authors used the IMF's GIMF model calibrated for the Czech Republic. 
This paper is organised as follows. Section 2 reviews the relevant literature and Section 3 outlines the structural DSGE model with an emphasis on its fiscal features. Section 4 quantifies the impacts of hypothetical and past fiscal devaluation on the Czech economy, and provides estimates for fiscal multipliers. The last section summarises the main findings.

\section{Related literature review}

The literature on fiscal devaluations is rich, but currently lacks empirical evidence for the Czech Republic. An overview of quantitative studies on fiscal devaluation and its effects on economic growth, employment, and net export in both the short- and long-term can be found in Koske (2013). In this overview, the short-term effects of fiscal devaluation on real GDP amount to 0.7 p.p. More recently, Gomes et al. (2016) assessed fiscal devaluations in Spain using a dynamic general equilibrium EAGLE model and estimated an increase in real GDP of $0.9 \%$ over three years. Vukšić and Holzner (2016) employed a partial equilibrium model to explore the likely effects of fiscal devaluation for seven countries in South-Eastern Europe and found a positive impact on output growth of around 0.2 p.p. An interesting theoretical contribution by Farhi et al. (2014) shows that fiscal devaluation can robustly replicate real allocations achieved under nominal exchange rate devaluation, even with a fixed exchange rate regime. Contrary to the conventional view in the literature, Erceg et al. (2018) note that fiscal devaluation might be contractionary on aggregate demand and inflation, especially under fixed exchange rates. There is a rich stream of literature on trade and fiscal consolidation which examines import tariffs and export subsidies using DSGE models with several rigidities. For instance, Lindé and Pescatori (2017) studied the robustness of the Lerner symmetry ${ }^{2}$ and found significant deviations from the symmetry if international asset markets are complete, there is a direct pass-through of tariffs and subsidies to prices, or exchange rate adjustment is gradual.

Fiscal multipliers are covered extensively in the empirical literature, with estimates stemming from various models, such as structural VAR models, RBC models, DSGE models, structural macroeconometric models, and single-equation approaches. Fiscal multipliers are quite sensitive to the underlying model, as is well documented in the meta-regression analysis by Gechert and Will (2012). The highest fiscal multipliers usually stem from macroeconometric models, while DSGE models tend to report the lowest multipliers. Nevertheless, the average fiscal multiplier across various types of models is less than 1 .

\footnotetext{
${ }^{2}$ Lerner (1936) demonstrated that combining an import tariff with an export subsidy should have an effect on the exchange rate such that price distortions from changes in trade policy are compensated and real allocations are unaffected.
} 
There is a growing literature on fiscal multipliers in the Czech Republic. A fiscal multiplier of 0.6 , which is assumed in the CNB's macroeconomic forecast, was estimated in Hřebíček et al. (2005) using both regression analysis, and structural simulation. Prušvic (2010) found the government expenditure multiplier to have a slightly lower value of 0.5 . A comprehensive set of fiscal multipliers is provided by Klyuev and Snudden (2011), in which the authors calibrated the IMF's GIMF model for the Czech Republic and found the highest multipliers for government consumption and investment, both reaching 0.4. Using the SVAR model, Valenta (2011) estimated the fiscal multiplier for government spending to be in the range of 0.3-0.6. Franta (2012) employed various identification schemes in structural VAR models and calculated fiscal multipliers for government spending and revenue shocks; however, these fiscal multipliers are in many cases unrealistically high, reaching values above 1 . Fiscal multipliers from the estimated DSGE model are available in Ambriško et al. (2015), with the highest fiscal multiplier of 0.6 calculated for both government consumption and social contributions paid by employers. Recently, Babecký et al. (2016) applied the DSGE model from Ambriško et al. (2015) to generate the priors for the structural VAR model and obtained the highest fiscal multiplier for government investment, with a value of 1 .

\section{The structural DSGE model}

The structural model employed in this paper is a simplified adaptation of the model used in Ambriško et al. (2015), ${ }^{3}$ which draws on the models developed by Andrle et al. (2009), Coenen et al. (2012), Galí (2011), and Galí et al. (2007). The small open economy is populated by two types of representative households. The first type is households which can save, called optimisers or Ricardian households; the second type is households which cannot save and which consume all of their disposable income, called 'rule-of-thumb' consumers or non-Ricardian households. The households consume a final consumption good, which is composed of private consumption and government consumption goods. The members of the households monopolistically supply a differentiated unit of labour to an employment agency, and the wage-setting follows Calvo contracts.

There are several production sectors in the economy, with monopolistic firms producing intermediate domestic, consumption, investment, export, import, and government goods. It is assumed that the pre-tax prices of consumption goods are rigid and that changes in consumption taxes are immediately and fully passed

\footnotetext{
${ }^{3}$ The main difference resides in the fiscal rules used, which are simplified and more general in this paper. Specifically, in this paper the cross-correlations between taxes are not imposed in the fiscal rules.
} 
on to consumer prices. ${ }^{4}$ Aside from private capital, there is government capital, which freely enters intermediate domestic goods production. Local currency pricing is assumed, ${ }^{5}$ which means that domestic importers take into account foreign prices and exchange rate movements to set sticky prices in domestic currency, whereas exporters' prices are sticky in foreign currency.

Government expenditure is divided into government consumption, government investment, unemployment benefits, and other social benefits. Government revenues come from consumption, labour, capital and lump-sum taxes, and social security contributions paid by employers. The government balances its budget by issuing bonds or by adjusting taxes. In the fiscal rules, fiscal instruments (taxes or expenditures) react to deviations of government debt and output from their respective targets. The central bank operates under an inflation targeting regime and follows a standard Taylor interest rate rule. The features of the model are shown in Figure 1, where black elements overlap with the g3 model, yellow elements represent the fiscal sector, and blue elements depict tax revenues. This presentation of the model focuses mainly on fiscal features; for a more detailed presentation of the model, see Ambriško (2016).

Figure 1. Diagram of the model

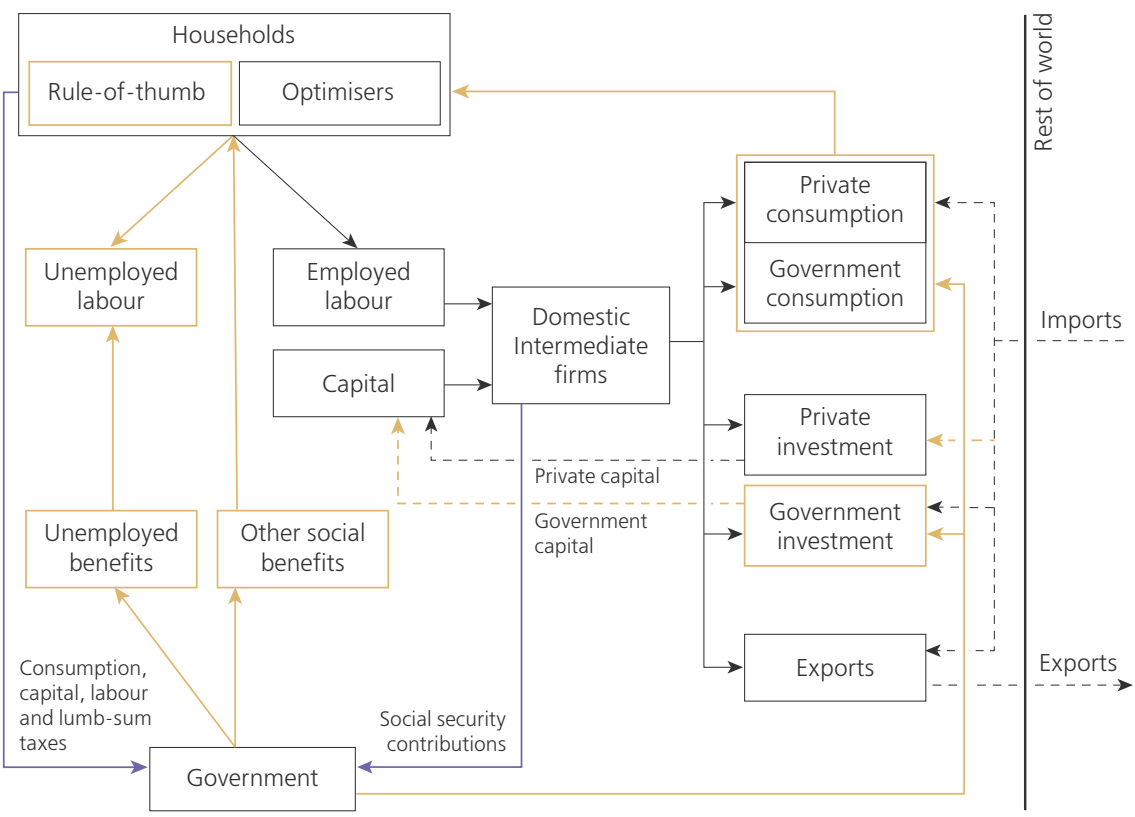

\footnotetext{
${ }^{4}$ The empirical literature seems to be in favour of large and fast VAT pass-through into prices; for instance, the evidence for Eurozone countries can be found in Benedek et al. (2015).

${ }^{5}$ Most transactions in the Czech economy are denominated in Czech crowns. Currently around $20 \%$ of firms are estimated to make financial transactions in euros. Local currency pricing therefore seems justifiable.
} 


\subsection{Households}

The economy is populated by a continuum of households indexed by $h \in[0,1]$. The households on the interval $[0, \gamma]$ are rule-of-thumb households, and those on $(\gamma, 1]$ are Ricardian households (also known as optimisers). Each household has a continuum of members indexed by a pair $(i, j) \in[0,1] \times[0,1]$, where index $i$ stands for the labour type and index $j$ determines the disutility of work, specified as $j^{\varphi_{n}}$, when the member is employed and zero otherwise, where $\varphi_{n} \geq 0$ is the elasticity of the marginal disutility of work. Both types of households maximise their lifetime utility function, given by:

$$
\begin{aligned}
E_{0} \sum_{t=0}^{\infty} \beta^{t} U_{h, t}^{k} & =E_{0} \sum_{t=0}^{\infty} \beta^{t}\left[\log \left(\mathcal{C}_{h, t}^{k}-\exp \left(\varepsilon_{t}^{h k}\right) \chi^{k} \mathcal{C}_{t-1}\right)\right. \\
- & \left.\theta \int_{0}^{1} \int_{0}^{L_{t}^{k}(i)} j^{\phi_{n}} d j d i\right]=E_{0} \sum_{t=0}^{\infty} \beta^{t}\left[\operatorname { l o g } \left(\mathcal{C}_{h, t}^{k}\right.\right. \\
& \left.\left.-\exp \left(\varepsilon_{t}^{h k}\right) \chi^{k} \mathcal{C}_{t-1}\right)-\frac{\theta}{1+\phi_{n}} \int_{0}^{1} L_{t}^{k}(i)^{1+\phi_{n}} d i\right]
\end{aligned}
$$

where $\beta \in(0,1)$ is the discount factor, superscript $k \in\{r, o\}$ distinguishes rule-ofthumb and optimiser households, $\mathcal{C}_{h, t}^{k}$ is the household-specific consumption aggregate, $\mathcal{C}_{t-1}$ is the lagged economy-wide level of consumption, $L_{t}^{k}(i) \in[0,1]$ is the fraction of members of type $i$ who are employed in households of type $k, \theta>0$ is a parameter associated with the disutility of the labour supply, $\chi^{k} \in[0,1)$ is the habit parameter, and $\varepsilon_{t}^{h k} \sim N\left(0, \sigma^{h k}\right)$ is an exogenous shock to internal habit formation. Household consumption is made up of private and government consumption goods as follows:

$$
\mathcal{C}_{t}^{k}=\left[\left(\alpha_{\mathcal{C}}\right)^{\frac{1}{v_{\mathcal{C}}}}\left(\mathcal{C}_{t}^{p k}\right)^{\frac{v_{\mathcal{C}}-1}{v_{\mathcal{C}}}}+\left(1-\alpha_{\mathcal{C}}\right)^{\frac{1}{v_{\mathcal{C}}}}\left(G_{t}^{k}\right)^{\frac{v_{\mathcal{C}}-1}{v_{\mathcal{C}}}}\right]^{\frac{v_{\mathcal{C}}}{v_{\mathcal{C}}-1}},
$$

where $\alpha_{c} \in(0,1]$ is the share of the private good in the consumption aggregate, and $v_{c}>0$ is the elasticity of substitution between the private and government consumption goods. The government good is equally available to all households, hence $G_{t}^{o}=G_{t}^{r}=G_{t}$, and is provided free of charge. Total capital in the economy $K_{t}$ is the CES aggregate of private $\left(K_{t}^{p}\right)$ and exogenously provided government capital $\left(K_{t}^{g}\right)$ :

$$
K_{t}=\left[\left(\alpha_{K}\right)^{\frac{1}{v_{K}}}\left(K_{t}^{p}\right)^{\frac{v_{K}-1}{v_{K}}}+\left(1-\alpha_{K}\right)^{\frac{1}{v_{K}}}\left(K_{t}^{g}\right)^{\frac{v_{K}-1}{v_{K}}}\right]^{\frac{v_{K}}{v_{K}-1}},
$$

where $\alpha_{K} \in[0,1]$ is the share of private capital in the capital aggregate and $v_{K}>0$ is the elasticity of substitution between private and government capital. 
Optimiser households respect the following budget constraint:

$$
\begin{aligned}
\left(1+\tau_{t}^{\mathcal{C}}\right) P_{t}^{\mathcal{C}} \mathcal{C}_{t}^{p o} & +P_{t}^{I} I_{t}^{p o}+B_{t}^{o} \\
\leq & \left(1-\tau_{t}^{W}+\tau_{t}^{U B}\right) \int_{0}^{1} W_{t}(i) L_{t}^{o}(i) d i \\
& +\left[\left(1-\tau_{t}^{K}\right) P_{t}^{K}+\tau_{t}^{K} \delta^{p} P_{t}^{I}\right] K_{t-1}^{p o} \\
& \quad+R_{t-1} B_{t-1}^{o}+P_{t}^{\mathcal{C}} O B_{t}^{o}-P_{t}^{\mathcal{C}} T_{t}^{o}+D_{t}^{o}
\end{aligned}
$$

where $\mathcal{C}_{t}^{o}$ is the optimisers' consumption; $I_{t}^{p o}$ denotes optimisers' investment in private capital $K_{t}^{p o} ; P_{t}^{c}$, and $P_{t}^{I}$ are the unit prices of consumption and investment goods; $P_{t}^{K}$ is the rental rate of capital; $R_{t}$ is the domestic nominal gross interest rate; $W_{t}(i)$, and $L_{t}(i)$ are the nominal wage and optimisers' hours worked for labour of type $i ; \tau_{t}^{\mathcal{C}}, \tau_{t}^{\mathrm{W}}$, and $\tau_{t}^{K}$ are effective tax rates on consumption, wages, and capital; $\tau_{t}^{U B}$ is the unemployment benefit rate; $O B_{t}^{o}$ are optimisers' other social benefits; $\delta^{p}$ is the depreciation rate of private capital; $B_{t}^{o}$ are nominal domestic bonds issued by the government and held by optimisers; and $T_{t}^{o}$, and $D_{t}^{o}$ are optimisers' lump-sum taxes, and dividends from monopolistic firms.

Optimisers own and accumulate a private stock of capital. The capital law of motion involves the type of intertemporal adjustment costs found in Kim (2003):

$$
K_{t}^{p o}=\left(K_{t-1}^{p o}\right)^{1-\delta^{p}}\left(\frac{I_{t}^{p o}}{\delta^{p}}\right)^{\delta^{p}}-\frac{\eta}{2}\left(\frac{I_{t}^{p o}}{I_{t-1}^{p o}}-1\right)^{2} K_{t-1}^{p o},
$$

where $\eta \geq 0$ is the investment adjustment cost parameter. The depreciation of capital is exempted from capital tax, as stated in the budget constraint for optimisers.

Rule-of-thumb households spend their entire budget on consumption:

$$
\begin{gathered}
\left(1+\tau_{t}^{\mathcal{C}}\right) P_{t}^{\mathcal{C}} \mathcal{C}_{t}^{p r} \\
\leq\left(1-\tau_{t}^{W}+\tau_{t}^{U B}\right) \int_{0}^{1} W_{t}(i) L_{t}^{r}(i) d i+P_{t}^{\mathcal{C}} O B_{t}^{r}-P_{t}^{\mathcal{C}} T_{t}^{r},
\end{gathered}
$$

where $\mathcal{C}_{t}^{r}, L_{t}^{r}(i), O B_{t}^{r}$, and $T_{t}^{r}$ are the rule-of-thumbs' consumption, hours worked for labour of type $i$, other social benefits, and lump-sum taxes.

\subsection{Fiscal block}

Government expenditure comprises government consumption, government investment, unemployment benefits and other social benefits provided to households, and interest payments on issued debt. The government can issue bonds to finance its expenditure. Government revenues are made up of consumption, labour, capital and lump-sum taxes, and social security contributions paid by 
employers. The total government budget balance can be computed by subtracting government expenditure from government revenue:

$$
\begin{gathered}
B B_{t}=\tau_{t}^{\mathcal{C}} P_{t}^{\mathcal{C}} \mathcal{C}_{t}^{p}+\left(\tau_{t}^{W}+\tau_{t}^{S}\right) W_{t} L_{t}+\tau_{t}^{K}\left(P_{t}^{K}-\delta^{p} P_{t}^{I}\right) K_{t-1}^{p} \\
+P_{t}^{\mathcal{C}} T_{t}-P_{t}^{G} G_{t}-P_{t}^{I} I_{t}^{g}-\tau_{t}^{U B} W_{t} L_{t}-P_{t}^{\mathcal{C}} O B_{t}-\left(R_{t-1}-1\right) B_{t-1},
\end{gathered}
$$

where $I_{t}^{g}$ is government investment, $\tau_{t}^{S}$ is the effective tax rate for social security contributions paid by employers, and $B_{t}, O B_{t}, T_{t}$, and $D_{t}$ are economy-wide aggregates of previously listed variables. The government's budget constraint is as follows: $B_{t-1}-B B_{t}=B_{t}$. Note that, in equilibrium, the level of government debt is constant and the government's budget is balanced. Government capital evolves according to a similar law of motion to private capital.

The government sets all fiscal instruments on the expenditure and revenue side using fiscal rules. All fiscal instruments react to deviations of output and real debt from their steady states. Unemployment benefits also respond to deviations of the unemployment rate from its natural rate. Allowing for feedback effects, fiscal instruments can act procyclically or countercyclically on the economy. For the purposes of illustration, only a couple of fiscal rules are specified here:

$$
\begin{aligned}
& \frac{G_{t}}{\bar{G}}=\left(\frac{G_{t-1}}{\bar{G}}\right)^{\rho_{g}}\left(\frac{Y_{t}}{\bar{Y}}\right)^{-\phi_{y g}}\left(\frac{b_{t}}{\bar{b}}\right)^{-\phi_{b g}} \exp \left(\varepsilon_{t}^{g}\right), \\
& \frac{\tau_{t}^{U B}}{\tau^{U B}}=\left(\frac{\tau_{t-1}^{U B}}{\tau^{U B}}\right)^{\rho_{u b}}\left(\frac{Y_{t}}{\bar{Y}}\right)^{-\phi_{y u b}}\left(\frac{b_{t}}{\bar{b}}\right)^{-\phi_{b u b}}\left(\frac{u_{t}}{u}\right)^{\phi_{u}} \exp \left(\varepsilon_{t}^{u b}\right), \\
& \frac{\tau_{t}^{\mathcal{C}}}{\bar{\tau}^{\mathcal{C}}}=\left(\frac{\tau_{t-1}^{\mathcal{C}}}{\bar{\tau}^{\mathcal{C}}}\right)^{\rho_{t c}}\left(\frac{Y_{t}}{\bar{Y}}\right)^{\phi_{y t c}}\left(\frac{b_{t}}{\bar{b}}\right)^{\phi_{b t c}} \exp \left(\varepsilon_{t}^{t c}\right),
\end{aligned}
$$

where for $x \in\{g, u b, t c\}$, the coefficients $\varphi_{y x}, \varphi_{b x}$, and $\varphi_{u}$ are feedbacks to output, debt, and unemployment respectively. $\rho_{x} \in[0,1)$ represent autoregression coefficients, and $\varepsilon_{t}^{x}$ are normally distributed innovations. If $\varphi_{y x}$ is positive (negative), then a given fiscal instrument has a countercyclical (procyclical) component. The fiscal rules for the remaining taxes and government expenditure are analogous to those listed.

\subsection{Monetary policy}

The central bank operates under a regime of inflation targeting, and sets the nominal gross interest rate according to the following Taylor rule:

$$
R_{t}=\left(R_{t-1}\right)^{\rho_{i}}\left[\bar{R}\left(\frac{\Pi_{t+4}^{\mathcal{C}_{4}}}{\bar{\Pi}}\right)^{\phi_{\pi}}\right]^{1-\rho_{i}} \exp \left(\varepsilon_{t}^{M}\right),
$$

where $\bar{R}$ is the steady state nominal gross interest rate, $\Pi_{t}^{c 4}=P_{t}^{c} / P_{t-4}^{c}$ is year-on-year CPI inflation, which excludes changes in indirect taxation, $\bar{\Pi}$ is the inflation target, 
$0 \leq \rho_{i}<1$ is the interest rate smoothing parameter, $\varphi_{\pi}>1$ is the feedback coefficient for deviations of inflation from the inflation target, and $\varepsilon_{t}^{M}$ is a normally-distributed monetary policy shock. The central bank tracks the year-on-year deviation of CPI inflation, excluding changes in indirect taxation, from its target four periods ahead. The exclusion of changes in indirect taxation is particularly relevant for fiscal devaluation, since the central bank does not raise interest rates in response to a higher tax rate on consumption.

\subsection{Calibration}

The parameters of the model were either calibrated or estimated on the basis of Czech data. In this section, the calibrated parameters of the model are described. For the purposes of comparison, the calibration is mostly as in Andrle et al. (2009). A complete list of calibrated parameters and steady state ratios can be found in Table 1 in the Appendix.

The discount factor $\beta$ is set so that the annualised equilibrium real interest rate equals $3 \%$. The disutility of labour supply parameter $\theta$ was set to 5 to pin down the steady state labour supply at a value of roughly $1 / 3$. The habit parameter is the same for both types of households and equals 0.75 . A high value for the habit parameter is found, for example, in the estimated DSGE model for the Czech Republic in Brázdik (2013). The capital share of output $\alpha$ equals $1 / 3$, which reflects the observed share of fixed investment in GDP. In the absence of empirical estimates, the share of the private good in the consumption good $\alpha_{c}$ and the share of private capital in the capital composite $\alpha_{K}$ is assumed to equal 0.8 , which is close to the values chosen by Coenen et al. (2011). The depreciation of capital, both private and government, is set to an annualised value of $6 \%$, which is in line with the estimates for the Czech Republic available in Hájková (2008) or Lízal (1999). The investment adjustment cost parameter $\eta$ equals 0.2 , and is calibrated to account for the high volatility of investment with respect to output. The gross inflation target is unitary since the model works with detrended variables.

On the revenue side, the model works with effective (or implicit) tax rates, and their steady states are set as follows: consumption tax at $25 \%$, wage tax at $29 \%$, capital tax at $15 \%$, and social security contributions paid by employers at $30 \%$. More detailed information about time series for effective tax rates in the Czech Republic is provided in the next section, 3.5. Other fiscal parameters were estimated; this concerns mainly output and debt feedback parameters in the fiscal rules. Nonetheless, the posterior mean of the debt feedback coefficient for consumption tax $\varphi_{b t c}$ turned out quite high (0.39), and for more reasonable impulse responses to consumption tax shock, this debt feedback parameter was calibrated to a lower value of 0.25 .

The steady state value for the unemployment rate is set to $6.5 \%$, which is the long-run average for the Czech Republic. The steady state ratio of government consumption to intermediate output is set to $25 \%$, the proportion of government 
investment in output is 3\%, unemployment benefits represent $0.3 \%$ of output, other social benefits make up $14 \%$ of output, and debt (bonds) is calibrated to $60 \%$ of output. These ratios can be expressed in nominal terms and with respect to the model's implied nominal GDP value; the resulting ratios are in line with Czech data. For example, the steady state nominal debt to GDP ratio is roughly $45 \%$, close to the observed level of government debt.

The proportion of imported goods in private consumption was set to $15 \%$; the proportion of imported inputs, which feeds into the total investment composite, equals $70 \%$; and the proportion of imported goods in the export good was calibrated to $55 \%$. These proportions were calibrated to match the proportions observed in Czech data. There is a significant degree of stickiness in each production sector, with the Calvo signalling parameters calibrated between 0.5 and 0.8 to account for different persistences in observed price deflators. The elasticities between varieties of goods are set to 6 , implying $20 \%$ mark-ups in production sectors. This is a plausible mark-up for European economies; for instance, Christopoulou and Vermeulen (2012) estimate the average markup for the manufacturing sector at $20 \%$ in selected European countries over the period 1993-2004. The elasticity between labour varieties is pinned down from equilibrium conditions. Known steady state values of the natural rate of unemployment, and the estimated value of the inverse of the Frisch elasticity, give a wage markup of approximately $18 \%$, which translates to an elasticity of labour varieties of 6.4. The elasticities between domestic and imported goods in consumption, investment, and export composite goods are all set to 0.5 , since these goods are deemed to be complements rather than substitutes. The price elasticity of exports equals 1.2, because export goods compete with other foreign goods. This choice is empirically supported by Tomšík (2000), who found higher price elasticity for exports than for imports in the Czech Republic. The elasticity of the risk premium with respect to foreign bonds is set at a relatively low value of 0.005 , which guarantees slow reversion of holdings of foreign bonds to its steady state.

Exogenous processes involve different degrees of persistence, captured by the $\rho$ coefficients. The exact values are provided in the Appendix. The persistence of productivity is set at 0.9 , which is in line with the literature on the real business cycle. The persistences of fiscal variables roughly follow the estimates from observed data, except for non-observed lump-sum taxes, where the persistence of 0.75 is chosen arbitrarily. The persistences of foreign exogenous variables are calibrated to account for their different degrees of historical variability. UIP sluggishness is set so as to generate a more realistic response by the nominal exchange rate to UIP shocks.

\subsection{Data}

The model is estimated on the basis of a set of 25 variables, covering the period 2000-2015 at quarterly frequency. The data used are on an accrual basis and consist of real GDP components (private consumption and investment, 
government consumption and investment, exports, imports), price deflators, nominal wages, financial variables (the three-month PRIBOR rate, the nominal exchange rate, the three-month EURIBOR rate, foreign demand, and producers' price indeces for the Euro Area), and fiscal variables. Fiscal variables include effective tax rates (on consumption, capital, wage, and social security paid by employers), social benefits, unemployment benefits, the primary budget balance, and government debt.

The data were collected from various sources: the Czech Statistical Office (CZSO), the Ministry of Finance (MoF), CNB, and Eurostat. Some source data published by the CZSO are already seasonally adjusted; the remaining data were seasonally adjusted using the TRAMO/SEATS method. The series for the exchange rate and for domestic and foreign interest rates were not seasonally adjusted. An overview of the data and their respective sources is available in Table 2 in the Appendix.

Effective tax rates were constructed from the CZSO data, using a slightly adjusted methodology suggested by Mendoza et al. (1994). ${ }^{6}$ The effective tax rate on consumption is constructed as follows:

$$
\tau_{t}^{\mathcal{C}}=\frac{I T_{t}-I T_{t}^{K}}{\mathcal{C}_{t}^{n p}+G_{t}^{n}-\mathcal{C} o E_{t}-\left(I T_{t}-I T_{t}^{K}\right)},
$$

where $I T_{t}$ are indirect taxes, $I T_{t}^{K}$ are indirect taxes of a capital nature (real property transfer tax, real property tax, and tax on emission allowances), $\mathcal{C}_{t}^{n p}$ is nominal private consumption, $G_{n}^{t}$ is nominal government consumption, and $\mathcal{C}_{o} E_{t}$ is the compensation of government employees. The effective rate on social contributions paid by employers equals:

$$
\tau_{t}^{S}=\frac{S C E_{t}}{W_{t}}
$$

where $S C E_{t}$ are social contributions paid by employers, and $W_{t}$ are wages and salaries (gross wages without social contributions paid by employers). The series for the effective wage tax rate is calculated as:

$$
\tau_{t}^{W}=\frac{D T_{t}-D T_{t}^{K}+S \mathcal{C} H_{t}}{W_{t}},
$$

where $D T_{t}$ are direct taxes, $D T_{t}^{K}$ are direct taxes of a capital nature (corporate income tax, tax on interest and dividends, and real property tax ${ }^{7}$ ), and $\mathrm{SCH}_{t}$ are social contributions paid by households. Finally, the effective tax rate on capital is computed as follows:

\footnotetext{
${ }^{6}$ I also work with the effective rate on social contributions paid by employers, whereas in Mendoza et al. (1994) all social contributions are included in the effective rate on labour income.

${ }^{7}$ Real property tax is recorded under both direct and indirect taxation, with the majority appearing under indirect taxation.
} 


$$
\tau_{t}^{K}=\frac{C T_{t}+I T_{t}^{K}+D T_{t}^{K}}{N O S_{t}},
$$

where $\mathcal{C} T_{t}$ are capital taxes, and $N O S_{t}$ is net operating surplus. All of the above effective tax rates are shown in Figure 2 in the Appendix.

Unemployment benefits were gathered from the MoF cash data, and adjusted into accrual terms by shifting paid benefits back a month (e.g. unemployment benefits paid in January correspond to the previous month, when the individual in question was unemployed - in this example, December).

Government investment is only reported by CZSO in nominal terms; therefore, the deflator for total investment is used as a proxy to construct real government investment. Private investment is subsequently calculated as the difference between real total investment and real government investment.

\subsection{Bayesian estimation}

Except for effective tax rates and domestic and foreign interest rates, input data are detrended by an HP filter with the standard smoothing parameter $\lambda=1600$ used for quarterly data. Observed data are linked to the model variables through the measurement equations. In these equations, the model variables are the sum of the observed data and the measurement error. Observed data and model variables are expressed in first differences, except for effective tax rates and domestic and foreign interest rates, which are linked on the levels. The standard deviation of the specific measurement error is calibrated at roughly $1 / 4$ of the standard deviation of the corresponding observed data.

The prior distributions for the estimated parameters of the model are chosen as follows. For parameters constrained on the interval $[0,1]$, the beta distribution is used. This is the case for the share of rule-of-thumb households in the economy $\gamma$ and the interest rate smoothing parameter $\rho_{i}$. The beta distribution for the share of rule-of-thumb households has a mean of $0.4{ }^{8}$ Due to the non-negativity constraint, the standard errors of shocks have priors from inverse gamma distributions. For the remaining parameters, the priors take the form of the normal distribution. To be more specific, the elasticities of substitution between the private and government components in the CES aggregates for consumption and capital, $v_{C}$ and $v_{K}$, have prior means set close to $1 .{ }^{9}$ The prior mean for the elasticity of the marginal disutility of work $\varphi_{n}$

\footnotetext{
${ }^{8}$ The selected mean of the distribution is justified by a Gallup poll, where $40 \%$ of approximately 1,000 Czechs questioned said that they did not expect to make ends meet (Ipsos Tambor 2012). A roughly similar share of $37 \%$ was used by Stork and Závacká (2010) in the calibration of their model.

${ }^{9}$ If the elasticity is exactly 1 , then the specification for consumption and capital aggregates collapses into a Cobb-Douglas form.
} 
equals 2.5. The prior mean for the inflation feedback coefficient is calibrated at 2 . The prior means for the debt feedback coefficients in the fiscal rules all equal 0.25 , for which a guaranteed stable solution of the model exists. The prior means for output feedback coefficients in the fiscal rules are centred at 0 , so as not to a priori rule out that a selected fiscal instrument may be pro- or countercyclical. The prior mean for the unemployment feedback coefficient is set at 1 so as to reflect the fact that unemployment benefits should move in line with the unemployment rate.

A Dynare toolbox for MATLAB was employed for Bayesian estimation of the selected parameters. ${ }^{10}$ Given the priors chosen and the data observed, the posterior kernel is simulated with the Metropolis-Hastings algorithm. In this algorithm 300,000 replications are set in each of five parallel chains. The scale parameter for the jumping distribution's covariance matrix was tuned to obtain a rough average acceptance ratio of $26 \%$ in the Metropolis-Hastings algorithm.

The estimation results are also summarised in Table 3 in the Appendix. The posterior mean of the share of rule-of-thumb households $\gamma$ equals $32 \%$, which is below its prior. The posterior mean of the inverse of Frisch elasticity $\varphi_{n}$ is slightly above the prior mean, suggesting lower elasticity of hours worked to wages. There is only a minor shift in the posterior means for the elasticities in CES aggregates for consumption $v_{c}$ and capital $v_{K}$ from their unitary prior means, indicating that the observed data are not very informative with respect to these parameters. As for monetary policy, the posterior mean for the inflation feedback coefficient in the policy rule $\varphi_{\pi}$ is found to be 1.9, which is slightly lower than its prior mean. The posterior mean for the interest rate smoothing parameter $\rho_{i}$ turned out higher than its prior, which reflects the relatively low volatility of the monetary policy rate in the Czech Republic.

Regarding fiscal parameters, the posterior means for the output feedback coefficients were found to be mainly positive, suggesting that the respective fiscal instruments are more or less counter-cyclical. This result is intuitive for unemployment benefits, which tend to be counter-cyclical on the economy. The only exception, with a negative posterior mean for the output feedback coefficient, is consumption tax. For consumption tax, there are several episodes in the Czech economy (e.g. VAT hikes during consolidations in 2012-2013 or the lower VAT rate on selected goods introduced in 2015) which support this procyclical behaviour. The posterior means of all the debt feedback coefficients are found to be positive, which helps to stabilise government debt outside of equilibrium and leads to a stable solution of the model. The posterior mean of the unemployment feedback coefficient $\varphi_{u}$ is slightly positive; nevertheless, it is well below its prior.

\footnotetext{
${ }^{10}$ For details of the toolbox see www.dynare.org.
} 


\subsection{Steady state}

The steady state of the model is computed on the basis of the calibrated and estimated ${ }^{11}$ parameters of the model. Since the model involves several price levels in production sectors, one price level is taken as a numeraire, and the remaining prices are expressed with respect to this numeraire, which ensures the stationarity of the model. Using substitutions within the system of steady state versions of the optimality conditions, steady state values for all the model variables can be computed numerically. The system of optimality conditions is then log-linearised around the steady state and solved using the IRIS toolbox. ${ }^{12}$

Since the model works with detrended variables, there is no inflation in the steady state. Furthermore, the steady state consumption of the two types of households is allowed to differ, with the consumption of optimisers being higher than the consumption of rule-of-thumb households, reflecting the idea that optimisers are wealthier than rule-of-thumb households. Specifically, $\frac{\mathcal{C}^{r}}{\mathcal{C}^{o}}=1.25$, the value also used by Coenen et al. (2011). The desired steady state consumption ratio is achieved by adjusting lump-sum taxes for rule-of-thumb households in the steady state. In this model, the actual steady state lump-sum taxes for rule-ofthumb households are negative, which means that rule-of-thumb households are subsidised by lump-sum transfers in the equilibrium.

\section{The results}

In this section, the model is used to evaluate the likely impact of past and hypothetical fiscal devaluation (i.e. a shift from direct to indirect taxation). The values of fiscal multipliers implied by the structural DSGE model are then presented.

\subsection{Fiscal devaluation}

For practical purposes, and given the lack of empirical literature, I use the model to evaluate the impact of a shift from direct to indirect taxation on the Czech economy. In the literature ${ }^{13}$ this kind of shift in taxes is called a 'fiscal devaluation'. The transmission mechanism behind fiscal devaluation is simple. A decrease in direct taxes is reflected in lower unit labour costs, reduced domestic producer prices, and increased price competitiveness of exported goods. On the other hand, higher indirect taxes make imported goods more expensive, while leaving exported goods unaffected. The prices of domestically produced goods remain roughly unchanged, since the shifts in direct and indirect taxes are in opposite directions.

\footnotetext{
${ }^{11}$ Estimated parameters are evaluated at their posterior means.

${ }^{12}$ IRIS is a toolbox for macroeconomic modelling and forecasting in MATLAB, developed by Beneš (2012). Further information on the IRIS toolbox is available at www.iris-toolbox.com.

${ }^{13}$ See for instance Koske (2013).
} 
A simulation of fiscal devaluation can provide a useful indication of whether the government can stimulate the economy (in terms of real GDP growth) by changing the composition of its taxes while keeping the government budget unaffected. I run several simulations to illustrate the results of this fiscal devaluation.

In the first simulation, consumption tax is raised and taxes associated with wages (wage tax, and social security contributions paid by employers) are decreased.

The ex-ante increase in consumption tax is calibrated so as to bring an additional $1 \%$ of GDP into the government budget. This is achieved by raising the effective tax rate on consumption by approximately 2 p.p. The decreases in taxes associated with wages are set so as to withdraw 1\% of GDP from the government budget, with the contribution of wage tax and social security contributions paid by employers being the same ( $0.5 \%$ of GDP). In effect, both tax rates on wages, and social contributions paid by employers drop by roughly 1.6 p.p. Overall, the ex-ante changes in selected taxes keep the government budget neutral. The shift in these taxes is immediate and permanent. The underlying model is thus recalibrated, and a new steady state and transition matrix are computed. In this simulation, the economy converges from the old steady state towards the new one. In the initial conditions, the simulation starts at the values of the old steady state, and is then transformed by the transition matrix with tax rates adjusted for the new economy to the new steady state. Furthermore, for the sake of this simulation, fiscal rules for the tax rates are turned off (e.g. output and debt do not deviate from the new steady states in response to the setting of taxes over time). This simulation is depicted with blue lines in Figure 3 in the Appendix. The lines represent percentage deviations from the old steady state.

This simulation shows that real GDP growth increases by approximately 0.5 p.p. in the first year, when the tax shift occurs from direct to indirect taxes. Nevertheless, this increase in real GDP growth is only temporary, as the economy gradually converges towards the new steady state. In what follows, I elaborate on the transmission of fiscal devaluation in my model. Domestic firms face lower labour costs, and thus are more competitive in foreign markets. Additional labour is hired to cover increased demand for domestic goods. In order to hire more labour, real wages rise, which allows households to spend more of their income on consumption. The trade balance improves in the short term due to increased international competitiveness, but then worsens because of an increase in imports, which are entering into consumption goods. The improvement in real GDP growth seems to be mainly driven by improved domestic demand, ${ }^{14}$ suggesting that fiscal devaluation might be effective in more closed economies as well.

Although the exchange rate depreciates on impact, CPI inflation slows because the effect of lower domestic producer prices dominates. Note that CPI inflation

\footnotetext{
${ }^{14}$ If the export/import channel is muted in my model (by setting the proportion of imported goods in consumption/investment/exported goods close to zero), then fiscal devaluation continues to have a significant effect on real GDP growth, amounting to around 0.4 p.p.
} 
in the model does not involve changes in indirect taxation, and represents socalled monetary policy inflation, which the central bank targets. Furthermore, it is assumed that the VAT changes are fully and immediately passed on to consumer prices. Therefore, if changes in indirect taxation are added to CPI inflation, then after-tax CPI inflation, which is relevant to the average consumer, is initially higher in response to the VAT hike. The central bank cuts the nominal interest rate in response to lower monetary policy inflation, and so the uncovered interest rate parity condition induces initial depreciation of the nominal exchange rate, which later begins to appreciate. This appreciation is driven by decreased foreign debt elastic risk-premium in the UIP condition, reflecting the accumulation of net foreign assets and an improved trade balance.

In the second simulation, both consumption tax and capital tax are raised, and taxes associated with wages are decreased (as in the first simulation). The respective contributions of hikes in consumption tax and capital tax to the government budget are equal ( $0.5 \%$ of GDP). The effective tax rate on consumption increases by approximately 1 p.p., while the effective tax rate on capital grows by 1.8 p.p. The reduction in effective tax rates on wages and social contributions paid by employers are the same as in the first simulation. The tax shift from direct taxes to consumption tax and capital tax is shown by the golden lines in Figure 3 in the Appendix. In this simulation, real GDP growth accelerates in the first year to the same degree as in the first simulation. In this simulation, the increase in consumption tax is gentler than in the first simulation, and thus private consumption accelerates faster over time. On the other hand, higher capital tax leads to a drop in private investment. As the part of investment goods is imported, this translates into the evolution of imports, which are lower than in the first simulation.

In the Czech Republic, the so-called Stabilisation Reform of 2008 provides an example of a kind of fiscal devaluation, but one more focused on decreases in direct taxes. During the Reform, the reduced VAT rate was increased from $5 \%$ to $9 \%$ (resulting in an estimated $+0.6 \%$ of GDP in the government budget). ${ }^{15}$ Conversely, personal income tax was decreased by the introduction of a $15 \%$ flat tax rate $(-0.6 \%$ of GDP), the corporate income tax rate was lowered from $24 \%$ to $21 \%(-0.4 \%$ of GDP), and a cap on social contributions was imposed $(-0.1 \%$ of GDP). The estimated effects of these tax shifts on the economy are shown by the golden lines in Figure 4 in the Appendix, with real GDP gaining 0.4 p.p. in 2008. Nonetheless, the Stabilisation Reform was also accompanied by significant cuts in government expenditure, namely in pensions (-0.5\% of GDP) and government consumption (-0.1\% of GDP). If these expenditure cuts are taken into account in considering tax changes, then the positive impact of fiscal devaluation on real GDP is somewhat muted, as is shown by the black lines in the same figure.

\footnotetext{
15 The ex-ante estimates given in parentheses are adopted from the Ministry of Finance.
} 
The quantitative impacts of hypothetical fiscal devaluation are within the range given by other empirical estimates, e.g. as summarised in Koske (2013). Overall, the model's simulations confirm the argument that the government can easily support the economy by appropriately shifting the composition of taxes from direct taxes to consumption tax and/or capital tax.

\subsection{Fiscal multipliers}

In this paper, the impact fiscal multipliers are defined as follows:

$$
f m_{i, t}=\frac{\frac{\Delta R G D P_{t}}{\overline{R G D P}}}{\frac{\Delta\left(F_{t} P_{t}^{F}\right)}{\overline{G D P}}}
$$

where $F_{t}$ denotes the selected fiscal instrument and $P_{t}^{F}$ its price. The numerator in the definition is the change in real GDP with respect to the level of real GDP in the steady state, and the denominator is the change in nominal fiscal revenue or expenditure expressed as a percentage of the nominal GDP in the steady state. Exact expressions for fiscal revenues or expenditures can be found from the equation for the government budget balance (7); for instance, capital tax revenues equal

$$
\tau_{t}^{K}=\left(P_{t}^{K}-\delta^{p} P_{t}^{I}\right) K_{t-1}^{p}
$$

The model's implied fiscal multipliers are listed in Table 4 in the Appendix. The fiscal multipliers are calculated according to Uhlig (2010), so these are netpresent value multipliers accumulated over time, discounted by the steady state real interest rate:

$$
f m_{i, T}=\frac{\sum_{t=1}^{T} \frac{\Delta R G D P_{t}}{\frac{\Delta G D P(\bar{R})^{t}}{R}}}{\sum_{t=1}^{T} \frac{\Delta\left(F_{t} P_{t}^{F}\right)}{\overline{G D P}(\bar{R})^{t}}}
$$

Notice that this kind of fiscal multiplier can be interpreted as the average discounted change in real GDP over the average discounted change in fiscal revenue/ expenditure. Fiscal multipliers are listed with their effects on real GDP for individual revenue and expenditure items in the government budget. The fiscal multipliers are calculated for the case of a temporary, one-year fiscal stimulus and for the case of a longer-lasting ten-year fiscal stimulus. The unexpected shocks to the fiscal instruments are set so that the ex-ante worsening of the government budget balance in the first year equals $1 \%$ of nominal GDP, and the value of the corresponding fiscal 
instrument is kept constant during the affected period. Moreover, the estimated fiscal rule is initially turned off for two years (keeping unaffected fiscal instruments at their steady states) in order to isolate the effects of affected fiscal instruments. Immediately turning on the fiscal rule would make the results somewhat blurred by feedback effects as defined in the fiscal rule. The estimated fiscal rule is treated as a good approximation of the fiscal policy settings in the long run, so the fiscal rule is turned off at the beginning of the simulations. This also means that the fiscal stimuli in the first two years are fully debt financed by the issue of new government bonds. After two years, the fiscal rule is turned on, and the government budget is balanced by adjusting fiscal instruments, as shown in (8).

Regarding the effect of a temporary fiscal stimulus on real GDP, it is government consumption and government investment that are most affected after the first year, with fiscal multipliers reaching 0.6 and 0.5 respectively. Social contributions paid by employers have a fiscal multiplier of 0.4 , followed by consumption tax, wage tax, and unemployment benefits, with a corresponding fiscal multiplier of 0.3 . The fiscal multipliers for other social benefits and lump-sum taxes are 0.2. The fiscal multiplier for capital tax is the lowest, at 0.1 . All values for fiscal multipliers with effects on real GDP are well below 1 .

The values of fiscal multipliers for government consumption and investment are not far from the CNB estimates of around 0.6 reported in Hřebíček et al. (2005), which are obtained from empirical estimates using regression analysis and structural simulation. On the other hand, these fiscal multipliers are slightly higher than the estimates by Klyuev and Snudden (2011) for the Czech Republic using the GIMF model. For instance, the one-year temporary fiscal multipliers for government consumption and investment are larger than their estimates ( 0.6 and 0.5 , compared to 0.4 for both government consumption and investment). On the revenue side, one-year fiscal multipliers for consumption tax and wage tax (0.3) are roughly 2-3 times higher than the estimates based on the GIMF model. According to both models, in this paper and the GIMF model, capital tax has the smallest fiscal multiplier ( 0.05 vs. 0.02$)$. In fact, these estimates of the fiscal multiplier for capital tax are roughly in line with the range found by Coenen et al. (2012) for the euro area (0.03-0.06).

Lastly, I compare the values of fiscal multipliers in this paper to those found in Ambriško et al. (2015). (As I mentioned above, the two papers share a similar model.) Some fiscal multipliers in this paper are higher (consumption and wage tax, lump-sum tax, unemployment benefits and other social benefits), which is explained by the higher estimated proportion of 'rule-of-thumb' households in this paper. On the other hand, the fiscal multiplier for the social contributions paid by employers is lower in this paper (in the first year, 0.4 vs. 0.6 ), which is largely the result of the lower calibrated value for the persistence of social contributions in my paper. Fiscal multipliers for government consumption and government investment attain roughly the same values in the short term in both papers. 
Comparing fiscal multipliers with the results reported in a meta-analysis by Gechert and Will (2012) based on 89 studies suggests that the rather low values of the fiscal multipliers for the Czech economy could be attributed to its high import intensity of GDP. In what follows, these DSGE-based fiscal multipliers should be viewed as lower-bound estimates compared to those produced by macroeconometric models, single-equation approaches, or VARs.

The fiscal multipliers for a ten-year fiscal stimulus have similar values in the short term to the multipliers for a temporary, one-year fiscal stimulus. In the long run, the fiscal multipliers for the ten-year fiscal stimulus are somewhat lower, and for other social benefits, capital tax, and lump-sum taxes, the long-run effect on real GDP is slightly negative. Lower fiscal multiplier values for a permanent stimulus are confirmed by several other structural models: see Coenen et al. (2012) for an overview of the effects of fiscal stimuli in DSGE models. The underlying reason is that a longer-lasting stimulus translates into higher government debt, which has to be financed by higher taxes. A large increase in taxes leads to a negative wealth effect, which crowds out private demand.

\section{Conclusion}

Fiscal devaluation, a budget-neutral shift from direct to indirect taxation, is an important economic concept. The transmission mechanism behind fiscal devaluation in an open economy is as follows. A decrease in direct taxes lowers unit labour costs, reduces domestic producer prices, and increases the price competitiveness of exports. On the other hand, higher indirect taxes make imports more expensive while leaving exports unaffected. Overall, economic growth is boosted by this tax shift.

Given the lack of the empirical estimates for the Czech Republic, I simulated fiscal devaluation using a structural fiscal DSGE model. My model is a simplified adaptation of the model in Ambriško et al. (2015) and essentially represents an extension of the CNB's core g3 model (Andrle et al., 2009) with a more comprehensive fiscal block. The model is estimated by Bayesian techniques for the small open economy of the Czech Republic.

The results show that real GDP growth can be boosted by approximately 0.5 p.p. in the first year when a budget-neutral tax shift of a magnitude of $1 \%$ of GDP occurs, from direct taxes associated with wages to consumption tax. Furthermore, for illustrative purposes, the model was used to evaluate one realworld example: the fiscal devaluation that occurred during the Czech Republic's 2008 Stabilisation Reform.

I also calculated fiscal multipliers for several revenue and expenditure categories of the government budget. The real GDP fiscal multipliers from the model suggest that the largest multipliers after the first year of a temporary fiscal stimulus are associated with government consumption (0.6), government investment (0.5), and 
social security contributions paid by employers ( 0.4 ), followed by consumption tax, wage tax, and unemployment benefits (all roughly 0.3 ), then other social benefits and lump-sum taxes (both 0.2), and finally capital tax (0.1).

These findings suggest that, in a small open economy, the government can easily boost economic growth by adjusting fiscal instruments appropriately, either changing multiple instruments at once (as in the case of fiscal devaluation) or adjusting them individually.

Appendix is available at

http://www.cbr.ru/eng/money-and-finance;

dx.doi.org/10.31477/rjmf.201901.67

\section{References}

Ambriško, R. (2016). Growth-Friendly Fiscal Strategies for the Czech Economy. CERGE-EI Working Papers, N 563.

Ambriško, R., Babecký, J., Ryšánek, J. and Valenta, V. (2015). Assessing the Impact of Fiscal Measures on the Czech Economy. Economic Modelling, 44(C), pp. 350-357.

Andrle, M., Hlédik, T., Kameník, O. and Vlček, J. (2009). Implementing the New Structural Model of the Czech National Bank. Czech National Bank Working Paper, N 2.

Babecký, J., Franta, M. and Ryšánek, J. (2016). Effects of Fiscal Policy in the DSGEVAR Framework: The Case of the Czech Republic. Czech National Bank Working Paper, N 9.

Barro, R. J. (1981). Output Effects of Government Purchases. Journal of Political Economy, 89(6), pp. 1086-1121.

Baxter, M. and King, R. G. (1993). Fiscal Policy in General Equilibrium. American Economic Review, 83(3), pp. 315-34.

Benedek, D., de Mooij, R. A., Keen, M. and Wingender, P. (2015). Estimating VAT Pass Through. CESifo Working Paper Series, N 5531.

Beneš, J. (2012). IRIS Toolbox Reference Manual. Ver. 2012-06-22.

Brázdik, F. (2013). Expected Regime Change: Transition Toward Nominal Exchange Rate Stability. Czech National Bank Working Paper, N 2.

Christopoulou, R. and Vermeulen, P. (2012). Markups in the Euro Area and the US over the Period 1981-2004: A Comparison of 50 Sectors. Empirical Economics, 42(1), pp. 53-77.

Coenen, G., Erceg, C. J., Freedman, C., Furceri, D., Kumhof, M., Lalonde, R., Laxton, D., Linde, J., Mourougane, A., Muir, D., Mursula, S., de Resende, C., Roberts, J., Roeger, W., Snudden, S., Trabandt, M. and in 't Veld, J. (2012). Effects of Fiscal Stimulus in Structural Models. American Economic Journal: Macroeconomics, 4(1), pp. 22-68. 
Coenen, G., Straub, R. and Trabandt, M. (2011). Fiscal Policy and the Great Recession in the Euro Area. Mimeo.

Coenen, G., Straub, R. and Trabandt, M. (2012). Fiscal Policy and the Great Recession in the Euro Area. American Economic Review, 102(3), pp. 71-76.

Erceg, C., Prestipino, A. and Raffo, A. (2018). The Macroeconomic Effect of Trade Policy. Society for Economic Dynamics Meeting Papers, N 221.

Farhi, E., Gopinath, G. and Itskhoki, O. (2014). Fiscal Devaluations. Review of Economic Studies, 81(2), pp. 725-760.

Franta, M. (2012). The Effects of Fiscal Policy in the Czech Republic: Evidence Based on Various Identification Approaches in a VAR Framework. Czech National Bank Working Paper, N 13.

Galí, J. (2011). The Return of the Wage Phillips Curve. Journal of the European Economic Association, 9(3), pp. 436-461.

Galí, J., López-Salido, J. D. and Vallés, J. (2007). Understanding the Effects of Government Spending on Consumption. Journal of the European Economic Association, 5(1), pp. 227-270.

Gechert, S. and Will, H. (2012). Fiscal Multipliers: A Meta Regression Analysis. Macroeconomic Policy Institute Working Paper, N 97.

Gomes, S., Jacquinot, P. and Pisani, M. (2016). Fiscal Devaluation in the Euro Area: A Model-Based Analysis. Economic Modelling, 52(PA), pp. 58-70.

Hájková, D. (2008). The Measurement of Capital Services in the Czech Republic. Czech National Bank Working Paper, N 11.

Hřebíček, H., Král, P. and Říkovský, M. (2005). An Up-date of Fiscal Impulse Quantification. Czech National Bank, mimeo. [In Czech].

Ipsos Tambor (2012). 40 Procent Čechů Bude Žit od Výplaty k Výplatě. January. [In Czech].

Kim, S. (2003). Structural Shocks and the Fiscal Theory of the Price Level in the Sticky Price Model. Macroeconomic Dynamics, 7(5), pp. 759-782.

Klyuev, V. and Snudden, S. (2011). Effects of Fiscal Consolidation in the Czech Republic. IMF Working Papers, N 65.

Koske, I. (2013). Fiscal Devaluation - Can it Help to Boost Competitiveness? OECD Economics Department Working Papers, N 1089.

Lerner, A. P. (1936). The Symmetry between Import and Export Taxes. Economica, 3(11), pp. 306-313.

Lindé, J. and Pescatori, A. (2017). The Macroeconomic Effects of Trade Tariffs; Revisiting the Lerner Symmetry Result. IMF Working Papers, N 151.

Lízal, L. (1999). Depreciation Rates in a Transition Economy: Evidence from Czech Panel Data. Prague Economic Papers, N 3.

Mendoza, E. G., Razin, A. and Tesar, L. L. (1994). Effective Tax Rates in Macroeconomics: Cross-country Estimates of Tax Rates on Factor Incomes and Consumption. Journal of Monetary Economics, 34(3), pp. 297-323.

Prušvic, D. (2010). Fiscal Stimuli and Fiscal Multipliers in Small Open Economies: The Case of the Czech Republic. Presented on the 40th Conference on Medium Term Economic Assessment, 23-25 September, Luxembourg. 
Štork, Z. and Závacká, J. (2010). Macroeconomic Implications of Fiscal Policy Measures in DSGE. Ministry of Finance of the Czech Republic Working Paper, N 1.

Tomšík, V. (2000). Analysis of Foreign Trade in the Czech Republic. Eastern European Economics, 38(6), pp. 43-68.

Uhlig, H. (2010). Some Fiscal Calculus. American Economic Review, 100(2), pp. 30-34.

Valenta, V. (2011). Interactions between Fiscal Policy and Real Economy in the Czech Republic: A Quantitative Analysis. Doctoral dissertation, University of Economics, Prague.

Vukšić, G. and Holzner, M. (2016). Trade and Fiscal Imbalances in Southeastern Europe: Can Fiscal Devaluation Help? Economic Systems, 40(4), pp. 568-581. 